\title{
The relationship between human capital components and innovation climate in public universities
}

\author{
Susan Bahrami* \\ Faculty of Humanity Sciences, University of Qom, Qom, Iran
}

\section{A RT ICLE INFO}

\section{Article history:}

Received 4 February 2017

Received in revised form

10 April 2017

Accepted 14 April 2017

\section{Keywords:}

Human capital components

Innovation climate

Universities

\begin{abstract}
A B S T R A C T
The aim of this study was to investigate the relationship between human capital components with innovation climate faculty members in the public universities. A multiple correlational survey design with a stratified random sampling $(\mathrm{N}=1085)$ was used. The data gathering instruments included human capital components with innovation climate questionnaires. The questionnaires' face and content validity confirmed by experts and their reliability were estimated $\left(\mathrm{r}_{1}=0.90\right)$ and $\left(\mathrm{r}_{2}=0.80\right)$ respectively through Cronbach's alpha coefficient. The gathered data was analyzed through descriptive and inferential statistics. The results showed that components of human capital were less than average level but level of education, professional skills were at average level and the means of innovation climate were less than average level. It was found a direct and significant relationship between scores of human capital components and innovation climate. Beta coefficients among human capital components and innovation climate were significant and no autocorrelation existed and regression model was significant. The study suggested that human capital components is a comprehensive, department wide program designated to improve employee satisfaction, strengthening workplace learning and helping employees had better manage change and transition.
\end{abstract}

(C) 2017 The Authors. Published by IASE. This is an open access article under the CC BY-NC-ND license (http://creativecommons.org/licenses/by-nc-nd/4.0/).

\section{Introduction}

Intellectual capital (IC) combines all the intangibles based on knowledge that an organization can use to attain a competitive advantage and create value (Hamel and Prahalad, 1994). Although there are numerous definitions of IC, three components appear consistently: human capital (HC) refers to the knowledge, competencies, experience, and creativity of the workforce as well as their attitudes and motivation (Bontis, 1998). Structural capital consist of all the structures, procedures, routines, cultural aspects, and data bases that permit an organization to codify, organize, and diffuse internally the knowledge and experiences created by the HC. Relational capital integrates the knowledge about relations with the organization's external partners such as customers, providers and local communities (Stewart, 1998). Inside the three components of intellectual capital, human capital, understood as both individual and group knowledge of company

\section{* Corresponding Author.}

Email Address: bahrami837@gmail.com

https://doi.org/10.21833/ijaas.2017.05.015

2313-626X/@ 2017 The Authors. Published by IASE.

This is an open access article under the CC BY-NC-ND license

(http://creativecommons.org/licenses/by-nc-nd/4.0/) employees, is exclusively main in determining innovation capacity of firms. We therefore reflect a broader definition of $\mathrm{HC}$ to include not only individual knowledge, but also the part of knowledge that arises from relationships between company personnel (Edvinsson and Malone, 1997).

More recently, several empirical studies have established a positive relationship between human capital and organizational performance. As, in a study of public listed firms in diverse industries, Youndt and Snell (2004) have found that human capital has significant effect on performance measures for example return on assets and return on equity. As a result of increasing attention paid to human capital, there are intensive interests in developing reliable indicators for human capital. Schumann (2001) debated that staffs should have equal opportunities to demonstration their potential to contribute. When staffs do not have such an opportunity, they could have the impression that the ratio of contributions and outcomes is invalid and based on information that is not representative. Van den Bos et al. (1997) advised that when people lack proper information on either their contributions or outcomes, they will emphasis their assessment of distributive justice on the information that is available. Therefore, when staffs lack proper 
information about their own and their co-workers' potential contributions, they shape their feelings of distributive justice by evaluating the differential outcomes they perceive, for example, varying development opportunities or financial rewards (Van den Bos et al., 1997). Staffs who then receive no or very few outcomes compared to other co-workers thus perceive distributive injustice. Bozbura et al., (2007) placed HC as the most significant asset of the Intellectual Capital, and then it is the source of creativity in the organization. HC is significant because it is believed to be a source of innovation and strategic renewal.

The nature of world economic growth is, in part, due to innovation speed. This is possible given the rapid technological development, shorter produce life cycles and to the higher rate of development of new products (Plessis, 2007). In this sense, innovation can be demarcated as the process that allows organizations to accumulate knowledge and technological capacities to improve productivity, cost reduction and values while, at the same time, contributes to the creation of new products and to the quality increase of existing ones. Organizational climate is defined as a set of shared insights regarding the policies, practices, and procedures that convey messages' regarding what is rewarded, sustained, and valued in an organization, and is often thought to arise through social interaction processes at the group level (Kuenzi and Schminke, 2009). Although research has generally examined universal organizational climate some scholars have lately focused on particular facet specific climates such as climate for innovation (Anderson and West, 1998; Eisenbeiss et al., 2008). Organizational climate can be determined by the perceptions individuals have of their workplaces, for example reflected by personal values and psychological desires (McMurray et al., 2010). Organizational climate is defined as a set of shared perceptions regarding the policies, practices, and processes that convey messages regarding what are rewarded, supported, and valued in an organization, and are often thought to emerge through social interaction processes at the group level (Kuenzi and Schminke, 2009). Ekvall (1996) argued that climate is a distinguishing of organizations that is best understood as a constellation of attitudes, feelings, and behaviours. The climate conveys messages about life within the organization and serves to uphold and continue a particular view of reality shared by members of the organization. Oldham and Cummings (1996) pointed out that an intelligence of being in charge can motivate staff to produce innovative products in complex and exciting work situations. Sternberg and Lubart (1996) suggested that promising innovation fosters creativity. Finally, Amabile (1988) argued that encouraging innovation, providing resources in the labour environment, and employing innovative management techniques all affect the organizational climate for innovation. Amabile (1996) argued that the social environment acting an important role in stimulating individual work motivation. In supplement research, we also found that when an individual is well integrated into an organization, has contact to adequate resources, and has leader inspiration and support, individual creativity growths. Several studies have explored similar questions in regard to school climate of innovation and creative training. A climate for innovation reflects norms and practices that encourage flexibility, the appearance of ideas, and learning. It also denotes norms and practices, supported and rewarded by the organization, that value taking charge and adjusting to changing contexts (West et al., 2003).

Rosse and Levin (2003) pointed to bureaucratic and convoluted systems in the progress and retention of staff associated to the business environment. Lepak and Snell's (2002) empirical research supports this contingent configurationally theoretical framework and the notion that different employment nodes are linked to variations in human capital value and uniqueness. Further, their findings propose that there looks to be a defined pattern of resource allocations and HR configurations related with different groups of employees. Furthermore, Lepak et al. (2007) found that organizations deployed high investment HR systems more for core employees than for support staffs in the service organizations they studied. HR demand and supply, implementing programs and evaluating outcomes) might be connected to organizational variables (e.g. the organization's strategy, life cycle stage, competitive environment) over some time horizons. Furthermore, Kumar (2008) believed the ultimate competitive advantage for any organization is a deep talent pool with active leaders at every level who are organized for future challenges. The present study was aimed to investigate the relationship between human capital and Innovation climate in public universities. The effects could pave the way to increase the quality of education services and improve the higher education performance.

\section{Materials and methods}

The present study employs a questionnaire survey approach to collect data for testing and research Question. Variables in the questionnaire comprise background information, human capital components and Innovation climate indicators in higher education. All variables require ten-point Likert style responses ranging from "strongly disagree" to "strongly agree". The population for the study is 1085 faculty members in public universities of the Isfahan. This study uses a stratified random sampling method to select 400 faculty members. The authors distribute 380 questionnaires and ask for the questionnaires to be completed by faculty members of the 380 returned questionnaires, 20 are incomplete. The residual 380 valid and complete questionnaires are intended for the quantitative analysis. Data were composed by two questionnaires: Drawing upon prior researches (luthans et al., 2004), this study adapts four aspects, 
including personal experience, level of education, professional skills and creative ideas in the construct of human capital with development of a twenty sixitem scale. Drawing upon prior researches (Ekvall, 1996), this study adapts six aspects, including commitment, positive relationship, shared view, freedom, idea-support, risk-taking in the construct of climate scale with development of a thirteen-item scale. To verify the questionnaires validity face and content method and authority opinions were utilized. Reliability coefficient of questionnaires were estimated through Cranach's alpha coefficient $\left(r_{1}=0.90\right)$ and $\left(r_{2}=0.80\right)$. To show the differences in human capital and Innovation climate among universities types, t-test, Fisher test, ANOVA, Multiple regressions were employed. A multiple comparison post hoc test with least significant difference (LSD) was used to determine which universities types were significantly different from the others.

\section{Results and discussions}

Most respondents (32.9\%) aged 35 to 50 years; most of them (83\%) Assistant Professor's degree. Most faculty members (37.9\%) had between 10 and 20 years of service. $22.5 \%$ of the examinees included female and $82.4 \%$ male. Research results showed that confidence intervals of human capital components show that means score of Personal experience was between 4.69 and 5.04 means score of Level of education was between 4.90 and 5.26 and Professional skills was between 4.86 and 5.20 and creative ideas was between 3.29 and 4.04 with probability of 99 percent. Research results showed that confidence intervals of innovation climate indicators show that means score of commitment was between 4.52 and 4.82 means score of positive relationship was between 4.50 and 4.82 and shared view was between 4.54 and 4.90 and freedom was between 3.20 and 3.56 and idea-support was between 4.38 and 4.70 and risk-taking was between 3.10 and 3.46 with probability of 99 percent.

Table 1 presents the results of multiple regression analysis regarding the effects of human capital components on innovation climate (p $=0.000$ ). Multiple correlation coefficients are 0.734 and modified determination coefficient is 0.538 . So 53.8 percent of response variable can be explained by a combination of human capital components

Table 2 shows the results of coefficients of Personal experience and innovation climate are positive and significant. Coefficient of Level of education and innovation climate is significant. Coefficient of Professional skills and innovation climate are positive and significant. Coefficient of creative ideas and innovation climate are positive and significant. $(\mathrm{p}=0.000)$.

This study uses variance inflation factors (VIFs) to examine the effect of multi co linearity. The values of the VIF associated with the predictors show a range from 1.06 to 2.55 which shows that there is no autocorrelation among them. So regression model is significant and predictive model can be showed as follow:

$Y=2.89+0.330 x 1+0.341 x 2+0.257 x 3+0.386 x 4$

Analysis of covariance showed that observed $\mathrm{F}$ in level $p \leq 0.05$ for relation of human capital components and innovation climate according to demographic characteristics is significant. Eta square for sex was 0.03 , for service background was 0.02 , for educational department was 0.005 and for university rank was 0.02 which are not statistically significant. But Eta square for age was 0.05 and for university type was 0.07 which are statistically significant.

Table 1: Multiple regression between HC components and innovation climate

\begin{tabular}{|c|c|c|c|c|c|c|c|}
\hline Source & ss & df & $\mathrm{ms}$ & $\mathrm{R}$ & $\mathrm{R}^{2}$ & $\mathrm{~F}_{\mathrm{ob}}$ & $P$ \\
\hline Regression & 370.43 & 5 & 77.26 & & & & \\
\hline Residual & 589.56 & 374 & 1.15 & 0.734 & 0.538 & 76.7 & 0.000 \\
\hline
\end{tabular}

Table 2: Correlation between HC components and innovation climate

\begin{tabular}{cccccc}
\hline Indicators & $\beta$ & Beta & Vif & tob & P \\
\hline HC components & 2.89 & - & - & 6.529 & 0.000 \\
Constant & 0.330 & 0.289 & 1.86 & 2.204 & 0.000 \\
Personal experience & 0.341 & 0.301 & 2.04 & 2.013 & 0.000 \\
Level of education & 0.257 & 0.121 & 1.06 & 1.743 & 0.002 \\
Professional skills & 0.386 & 0.312 & 2.55 & 2.683 & 0.000 \\
creative ideas & & & & &
\end{tabular}

Research results showed that the components of human capital such as personal experience and creative ideas were less than average level but level of education and professional skills were at average level. The indicators of innovation climate such as commitment, positive relationship, shared view, freedom, idea-support, risk-taking were less than average level. Results of this study are almost compatible with a study that showed that the empirical research supports this contingent configurationally theoretical framework and the notion that different employment nodes are linked to variations in human capital value and uniqueness. Further, their findings propose that there looks to be a defined pattern of resource allocations and HR configurations related with different groups of employees (Lepak and Snell's, 2002). 
In general, there is significant multiple correlation between the human capital components including Personal experience, Level of education, Professional skills, creative ideas and the innovation climate in the studied universities. The beta coefficients have been as 0.289 between Personal experience and innovation climate, 0.301 between Level of education and innovation climate, 0.121 between Professional skills innovation climate, 0.312 creative ideas and innovation climate all of which are statistically significant. The variance inflation factor for explanatory variables has been at least 1.06 to 2.55, which shows that there is no conformity between them. Results of this study are almost compatible with a study that pointed out that an intelligence of being in charge can motivate staff to produce innovative products in complex and exciting work situations (Oldham and Cummings, 1996). Sternberg and Lubart (1996) suggested that promising innovation fosters creativity. Finally, Amabile (1988) argued that encouraging innovation, providing resources in the labour environment, and employing innovative management techniques all affect the organizational climate for innovation. Amabile (1996) argued that the social environment acting an important role in stimulating individual work motivation. Lepak et al. (2007) found that organizations deployed high investment HR systems more for core employees than for support staffs in the service organizations they studied. HR demand and supply, implementing programs and evaluating outcomes) might be connected to organizational variables (e.g. the organization's strategy, life cycle stage, competitive environment) over some time horizons. Furthermore, Kumar (2008) believed the ultimate competitive advantage for any organization is a deep talent pool with active leaders at every level who are organized for future challenges.

\section{Conclusion}

Higher education has historically been slow to accept many corporate management processes. HC is a widely-used strategy in business and industry and occurs in many forms from the highly structured to the informal. Nevertheless of the process that is implemented, the purpose for talent management in these environments is quite clear. Our findings have two important implications: Human resource managers recruit and develop the best and brightest employees as a means of attaining competitive advantage. So as to improve human capital components, knowledge of how the concept is related to and affected by other organizational variables is required.

\section{References}

Amabile TM (1988). A model of creativity and innovation in organizations. Research in Organizational Behavior, 10(1): 123-167.

Amabile TM (1996). Creativity in context. Westview Press, Colorado, USA.
Anderson NR and West MA (1998). Measuring climate for work group innovation: Development and validation of the team climate inventory. Journal of Organizational Behaviour, 19(3): 235-258.

Bontis N (1998). Intellectual capital: An exploratory study that develops measures and models. Management Decision, 36(2): 63-76.

Bozbura FT, Beskese A, and Kahraman C (2007). Prioritization of human capital measurement indicators using fuzzy AHP. Expert System and Applications, 32(4): 1100-1112.

Edvinsson L and Malone MS (1997). Intellectual capital: Realizing your company's true value by finding its hidden brainpower. Harper Collins Publishers, Inc, New York, USA.

Eisenbeiss SA, Van KD, and Boerner S (2008). Transformational leadership and team innovation: Integrating team climate principles. Journal of Applied Psychology, 93(6): 1438-1446.

Ekvall G (1996). Organizational climate for creativity and innovation. European Journal of Work and Organizational Psycholog, 5(1): 105-123.

Hamel G and Prahalad CK (1994). Competing for the future. Harvard Business School Press, 72(4): 122-124.

Kuenzi M and Schminke M (2009). Assembling fragments into a lens: A review, critique, and proposed research agenda for the organizational work climate literature. Journal of Management, 35(3): 634-717.

Kumar TN (2008). Leaders at all levels: Deepening your talent pool to solve the succession crisis. Management \& Change. 12(2):184-189.

Lepak DP and Snell's A (2002). Examining the human resource architecture: The relationships among human capital, employment, and human resource configurations. Journal of Management, 28(4): 517-543.

Lepak DP, Taylor MS, Teklead A, Marrone JA, and Cohen DJ (2007). An examination of the use of high-involvement human resource systems for core and support employees. Human Resource Management, 46(2):223-246.

Luthans F, Luthans KW, and Luthans BC (2004). Positive psychological capital: Beyond human and social capital. Business Horizons, 47(1): 45-50.

McMurray AJ, Pirola-Merlo A, Sarros JC, and Islam MM (2010). Leadership, climate, psychological capital, commitment, and wellbeing in a non-profit organization. Leadership \& Organization Development Journal, 31(5): 436-457.

Oldham GR and Cummings A (1996). Employee creativity: Personal and contextual factors at work. Academy of Management Journal, 39(3): 607-634.

Plessis M (2007). The role of knowledge management in innovation. Journal of Knowledge Management, 11(4): 20-29.

Rosse JG and Levin RA (2003). The Jossey-Bass academic administrators' guide to hiring. Jossey-Bass, San Francisco, USA.

Schumann PL (2001). A moral principles framework for human resource management ethics. Human Resource Management Review, 11(1/2): 93-111.

Sternberg RJ and Lubart TI (1996). Investing in creativity. American Psychologist, 51(6):677-688.

Stewart TA (1998). Intellectual capital, the new wealth of organizations. Performance Improvement, 37(7): 56-59.

Van den Bos K, Lind EA, Vermunt R, and Wilke HAM (1997). How do I judge my outcome when I do not know the outcome of others? The psychology of the fair process effect. Journal of Personality and Social Psychology, 72(5): 1034-1046.

West MA, Borrill CS, Dawson JF, Brodbeck F, Shapiro DA, and Haward B (2003). Leadership clarity and team innovation in health care. The Leadership Quarterly, 14(4): 393-410. 
Youndt MA and Snell SA (2004). Human resource configurations, intellectual capital, and organizational performance. Journal of
Managerial Issues, 16(3): 337-360. 